ISSN 0130-8521. Передгірне та гірське землеробство і тваринництво. 2021. Вип. 70 (2)

DOI: $10.32636 / 01308521.2021-(70)-2-5$

УДК 633.1:632.9

O. V. SNIZHOK, Candidate of Agricultural Sciences

Institute of Agriculture of Western Polissia of NAAS

Rivnenska street, 5, v. Shubkiv, Rivne district, Rivne region, 35325,

e-mail:vs_rapv@ukr.net

\title{
EFFICIENCY OF THE PROTECTION SYSTEM AND TREATMENT OF THE SOIL AGAINST HARMFUL ORGANISMS IN THE MAIZE CROPS FOR GRAIN
}

In recent years, there has been an annual deterioration in the phytosanitary condition of crops. One of the main factors of this phenomenon was the destabilization of the land use system and the disturbance or absence of crop rotations, which led to a high potential soil contamination by weeds and the accumulation of pests and diseases.

The article presents the results of research to determine the impact of different tillages and protection systems on the species composition of weeds, diseases and pests in maize crops, which were held in 2019 - 2020 on the territory of the Institute of Agriculture of Western Polissia of NAAS in 4-field crop rotation.

Studies are conducted on the general background of fertilizer in the norms recommended for crop rotation in the region.

The use of shelf tillage contributed to a faster passage of the phases of development of maize plants by 3-4 days, compared to non-shelf tillage.

It is established that tillage has a significant impact on the accumulation of pests, in particular, it is clearly traced by the number of weeds. The largest number of weeds was observed in the variants without herbicide spraying by surfacial soil cultivation and amounted to $545.6 \mathrm{pc} . / \mathrm{m}^{2}$, which is 2 times higher than by the shelf tillage $\left(277.1 \mathrm{pc} . / \mathrm{m}^{2}\right)$. That is, after moldboard tillage and spraying with herbicides, the number of weeds was $96,8 \%$ lower compared to the control. A slightly smaller difference in the influence of soil cultivation was monitored on the development and spread of diseases and pests. Against them, the main deterrent was still chemical protection. In the variants without insecticide, the population of maize hairy aphids was $85 \%$. The use of Belt $(0.15 \mathrm{l} / \mathrm{ha})$ made it possible to reduce the plant pest population by 3.5 times.

Technical efficiency of fungicide Retengo (0.5 1/ha) against fusarium was at the level of $87.1-90.0 \%$, gray rot $-78.3-80.1 \%$ and helminthosporiosis $79.4-81.4 \%$, depending on the tillage.

The $20-22 \mathrm{~cm}$ shelf- and $10-12 \mathrm{~cm}$ surfacial processing systems ensured corn yields of 6.90 and $6.28 \mathrm{t} / \mathrm{ha}$ of grain, respectively, compared to the $6-8 \mathrm{~cm}$ nondump system (5.36 t/ha). However, the combination of treatment with an intensive protection system allowed to increase the yield to 11.83 and $10.63 \mathrm{t} / \mathrm{ha}$. 
(C) Snizhok O. V., 2021

Key words: tillage, shelf, shallow, surfacial, maize, species composition, weeds, diseases, pests, herbicides, fungicides.

\section{Сніжок О. В.}

Інститут сільського господарства Західного Полісся НААН

Ефективність системи захисту та обробітку грунту проти шкідливих організмів у посівах кукурудзи на зерно

Останніми роками спостерігається щорічне погіршення фітосанітарного стану посівів сільськогосподарських культур. Одним із головних чинників такого явища стала дестабілізація системи землекористування й порушення або відсутність сівозмін, що призвело до високої потенційної засміченості грунту бур'янами та накопичення шкідників і хвороб.

Представлено результати досліджень щодо визначення впливу різних обробітків грунту та системи захисту на видовий склад бур'янів, хвороб та шкідників у посівах кукурудзи, які проведено у 2019-2020 рр. на території Інституту сільського господарства Західного Полісся НААН у 4-пільній сівозміні.

Дослідження проводили на загальних фонах удобрення в нормах, рекомендованих для культур сівозміни в умовах області.

Використання полицевого обробітку грунту сприяло більш швидкому проходженню фаз розвитку рослин кукурудзи на 3-4 доби порівняно 3 безполицевими обробітками.

Встановлено, що обробіток грунту має значний вплив на накопичення шкідливих організмів, зокрема це чітко простежується щодо кількості бур'янів. Найбільшу кількість бур'янів спостерігали на варіантах без обприскування гербіцидами за поверхневого обробітку грунту, яка становила 545,6 шт./м², що в 2 рази більше ніж за полицевого $(277,1$ шт./м²). Тобто за полицевого обробітку грунту та обприскування гербіцидами чисельність бур'янів була на 96,8 \% нижчою порівняно 3 контролем. Дещо менше різниця впливу обробітку грунту простежувалася на розвиток та поширення хвороб i шкідників. Проти них головним стримуючим чинником все ж таки $є$ хімічний захист. На варіантах без інсектициду заселеність попелицею кукурудзяною волохатою становила $85 \%$. Застосування белту $(0,15$ л/га) дозволило в 3,5 разу знизити заселеність рослин шкідником.

Технічна ефективність фунгіциду ретенго (0,5 л/га) проти фузаріозу була на рівні 87,1-90,0 \%, сірої гнилі - 78,3-80,1 \% та гельмінтоспоріозу 79,4-81,4\% залежно від обробітку грунту.

Полицева на 20-22 см і мілка на 10-12 см системи обробітку грунту забезпечили врожайність зерна кукурудзи відповідно 6,90 і 6,28 т/га порівняно 3 поверхневою системою на 6-8 см (5,36 т/га). Проте поєднання обробітку 
грунту з застосуванням системи захисту культури зумовило збільшення врожайності до 11,83 і 10,63 т/га.

Ключові слова: обробіток грунту, полицевий, мілкий, поверхневий, кукурудза, видовий склад, бур'яни, хвороби, шкідники, гербіциди, фунгіциди.

Introduction. Changing the priorities of modern agriculture on the background of further soil degradation necessitates improving the system of tillage for crop rotation in the direction of minimization, taking into account the type of crop rotation, quantity and quality of post-harvest residues, fertilizer level, phytosanitary condition of crops, technical capabilities of farms [1, 9, 11 13, 21].

Tillage is the basis and an important component of any technology for growing field crops. It aims to increase soil fertility and ensure stable yields of high quality with the lowest cost of material and energy resources. In the existing zonal integrated protection systems, agrotechnical measures operate for a long period and have a favorable effect on the general phytosanitary condition of the agrobiocenosis $[2,4,5,11,20,14,21,25$, 27]

Destabilization of the land use system and disturbance or absence of crop rotations has led to high potential soil contamination with seeds and vegetative germs of weeds, accumulation of pests and infections [8, 10, 12 , $17,18,22]$.

In their works, most scientists and practitioners believe that now in crop rotations of different soil-climatic regions of Ukraine it is necessary to carry out different-depth tillage taking into account the agrophysical properties of soil and biological characteristics of crops, using tools of both shelf and non-shelf type [13, 21, 29]. Therefore, the main task in modern agriculture in the absence of sufficient material resources for the use of energy-intensive technologies is to differentiate in depth and methods of tillage $[11,21,28,29,31]$.

Numerous experiments have shown that in crop rotations the number of weed seeds in the soil per rotation decreases three to four times, and the number and weight of weeds in crops, respectively, by $62-64$ and 36-74\% $[12,17,18,22,23]$. Moreover, the most effective measure to control the level of weeds in different agrophytocenoses of crop rotation is the main tillage. Its share in total weed control is about $60 \%[11,14,21]$.

It is believed that when applying the soil protection system of tillage there is a sharp increase in weediness of the fields and a change in the species composition of weeds in the direction of increasing the proportion of difficult to root and most harmful species $[12,19,25]$. At the same time, 
other researchers believe that when the soil is shelfless tilled, weed seeds are preserved in the deep layers of the soil and lose their viability, creating conditions for clearing the soil of weed seeds [32, 33]. However, according to the literature, it is noted that the combination of peeling and tillage provides a reduction of weeds in annual weeds by 2.2 times, and perennial root crops - 10.5 times $[2,9,14,31]$.

Due to the fact that maize plants grow very slowly at the beginning of the growing season, they cannot compete with weeds that are adapted to cool spring days, quickly forming a strong aboveground part and root system, suppressing crops. Weed infestation reduces crop productivity by $35-50 \%[4,5,7,10,17,19,26,28,30]$.

With this level of potential clogging, pest growth and disease development, large-scale use of chemical pesticides is required to preserve the crop, which is part of a comprehensive integrated system of protection of cultivated plants from pests [10, 14, 22, 25, 29].

The purpose of the work is to study the impact of the system of protection and different tillage on the species composition of weeds, diseases and pests of corn for grain in the conditions of Western Polissia.

Materials and methods. The experiments were conducted on the territory of the Institute of Agriculture of Western Polissia of NAAS during 2019-2020.

The soil of the experimental plot is dark gray podzolic. Studies are carried out on the general backgrounds of fertilizer in the norms recommended for crops in the region $\left(\mathrm{N}_{120} \mathrm{P}_{90} \mathrm{~K}_{120}\right)$. The accounting area $50 \mathrm{~m}^{2}$, three repetitions. Culture - corn hybrid DKS 3972.

Shelf tillage included stubble peeling with BDT-3 discs, plowing with PLN-5-35 plow to a depth of 20-22 cm, cultivation with AG-2.4 unit and pre-sowing tillage with RVK-3.6 unit.

Shallow tillage included stubble peeling with BDT-3 discs, cultivation with AG-2.4 unit to a depth of $10-12 \mathrm{~cm}$ and pre-sowing tillage with RVK-3,6 unit.

Surface tillage included only cultivation with the AG-2.4 unit to a depth of 6-8 cm.

Spraying of corn with soil herbicide Frontier Optima (1.2 1/ha) was carried out immediately after sowing, with insurance herbicide Milagro 240 SC $(0.6$ l/ha $)$ - In the phase of 6 leaves. Retengo fungicide $(0.5$ 1/ha) was applied in the 8-leaf phase, Belt insecticide $(0.15 \mathrm{l} / \mathrm{ha})$ in the 10 -leaf phase.

Weeds were counted before herbicide spraying, as well as 7 and 14 days after spraying. The species composition of weeds and the number per 1 
$\mathrm{m}^{2}$ were determined.

Records of diseases and pests were performed according to the method of V. P. Omeliuta [16]. To determine the disease, 10 plants were taken at 10 sites and the development and spread of the disease were determined according to the actually occupied by mycelium or spots in the area of leaves and stems according to the E. E. Geshel scale.

The technical efficiency of the drugs, as well as their economic efficiency was determined by the method of S. O. Trybel, D. D. Sigariov, M. P. Sekun [15]. During the harvesting period, the structural analysis of corn and crop accounting were determined, mathematical data processing was performed [6].

Results and discussion. As a result of the conducted researches it is noted that on variants where shelf and shallow tillage of a corn were carried out, sprouts of maize for grain appeared 3-5 days earlier than on a variant where surface cultivation was carried out (on shallow on 10-12 cm and superficial on 6-8 cm of tillage there is an increase in the density of the arable layer, compared with the $20-22 \mathrm{~cm}$ shelf tillage). The weather conditions also made their adjustments. Thus, during the years of research at the time of sowing corn (III decade of April), the average daily air temperature was within the climatic norm. However, the amount of precipitation in 2020 was only $3.6 \mathrm{~mm}$, less than the long-term average of $37.4 \mathrm{~mm}$, which slightly reduced the rate of grain germination. In the study area, May is characterized by high humidity. Because in two years more than $130 \mathrm{~mm}$ of precipitation fell while climatic norm is $76.0 \mathrm{~mm}$.

The weather conditions of the summer months were optimal for the vegetation of corn. During the growing season of corn, the sum of effective temperatures $\left(>10^{\circ} \mathrm{C}\right.$ ) in 2019 was $1199.1^{\circ} \mathrm{C}$, in $2020-1121.8^{\circ} \mathrm{C}$.

It is noted that the use of shelf tillage contributed to a faster passage of the phases of development of corn plants for 3-4 days, compared with non-shelf tillage.

During the study period, the species composition of weeds was represented mainly by: Apera spica venti L. $\left(27.0-114.0 \mathrm{pcs} / \mathrm{m}^{2}\right)$, Viola arvensis Murr. (22.5-303.6 pcs $\left./ \mathrm{m}^{2}\right)$, Tripleurospermum inodorum L. (1.0$\left.8.0 \mathrm{pcs} / \mathrm{m}^{2}\right)$, Stellaria media L. (2.0-14.5 pcs $\left./ \mathrm{m}^{2}\right)$, Thlaspi arvense L. (1.2$\left.5.2 \mathrm{pcs} / \mathrm{m}^{2}\right)$, Polygonum convolvulus L. (2.5-34.0 pcs $\left./ \mathrm{m}^{2}\right)$, Brassica napus $L$. (1.0-9.0 pcs $\left./ \mathrm{m}^{2}\right)$, Chenopodium album L. (2.5-16.5 pcs $\left./ \mathrm{m}^{2}\right)$ and others.

The largest number of weeds was observed in the variants without herbicide spraying after surface tillage and was $545.6 \mathrm{pcs} / \mathrm{m}^{2}$, which is 2 
times higher than by the shelf-tillage $\left(277.1 \mathrm{pcs} / \mathrm{m}^{2}\right)$ and 10.2 times higher than on variant with herbicides (Fig.).

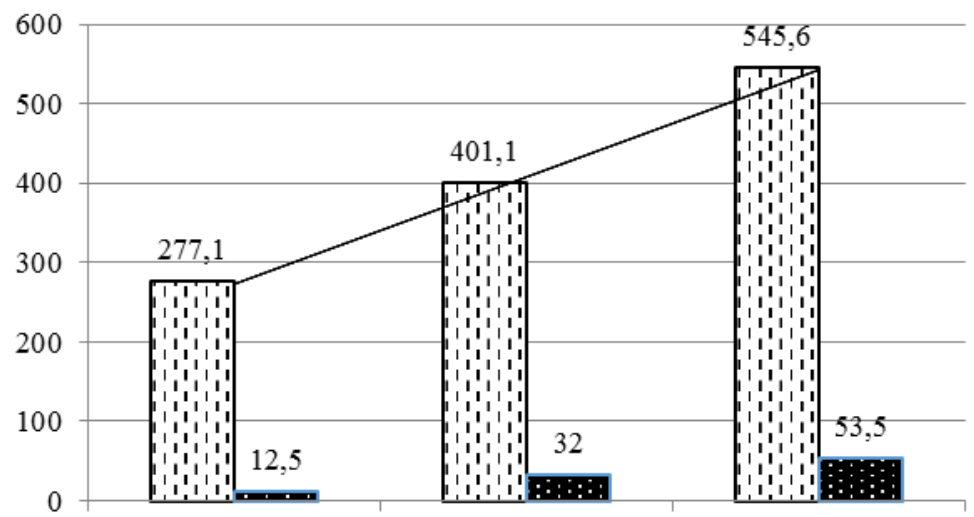

Shelf-tillage by $20-22$ Shallow by $10-12 \mathrm{~cm}$ Surfacial by $6-8 \mathrm{~cm}$ $\mathrm{cm}$ Without herbicides

$\cdots$ Intensive protection system

Fig. Influence of tillage and protection system on the number of weeds on maize crops (2019-2020)

According to the results of research under the intensive protection system, a similar trend was observed, ie, the minimum number of weeds for both the period of germination and the period of ripening of corn was observed during shelf tillage.

The first signs of herbicide action were observed on day 6 after spraying. Yellowing and deformation of the tops was observed on such weeds as bitter birch, white quince, knotweed, rake, rapeseed.

Studies have shown that the highest technical efficiency of herbicides was observed on day 14 after spraying and shelf tillage (96.8\%), as on day 30 a new wave of weeds began, in particular, Viola arvensis Murr. and horsetail (Table 1).

During the years of research at the time of harvest, the weight of weeds in the variants without herbicides was $330.1-578.3 \mathrm{~g} / \mathrm{m}^{2}$ depending on the tillage, while in the variants where herbicides were used 44.6-111.4 $\mathrm{g} / \mathrm{m}^{2}$ respectively (Table 1 ). 
ISSN 0130-8521. Передгірне та гірське землеробство і тваринництво. 2021. Вип. 70 (2)

1. The effectiveness of herbicides in maize crops (IAWP NAAS, 20192020)

\begin{tabular}{|c|c|c|c|}
\hline \multicolumn{2}{|c|}{ Variant } & $\begin{array}{c}\text { Technical } \\
\text { efficiency, \% }\end{array}$ & $\begin{array}{l}\text { Weight of weeds, } \\
\mathrm{g} / \mathrm{m}^{2}\end{array}$ \\
\hline \multirow{2}{*}{$\begin{array}{l}\text { Shelf by } 20- \\
22 \mathrm{~cm}\end{array}$} & $\begin{array}{c}\text { Without pesticides } \\
\text { (control) }\end{array}$ & 0 & 330,1 \\
\hline & $\begin{array}{c}\text { Integrated } \\
\text { protection system }\end{array}$ & 96.8 & 44.6 \\
\hline \multirow{2}{*}{$\begin{array}{l}\text { Shallow by } \\
10-12 \mathrm{~cm}\end{array}$} & $\begin{array}{l}\text { Without pesticides } \\
\text { (control) }\end{array}$ & 0 & 462.5 \\
\hline & $\begin{array}{c}\text { Integrated } \\
\text { protection system }\end{array}$ & 93.5 & 88.3 \\
\hline \multirow{2}{*}{$\begin{array}{l}\text { Surfacial by } \\
6-8 \mathrm{~cm}\end{array}$} & $\begin{array}{l}\text { Without pesticides } \\
\text { (control) }\end{array}$ & 0 & 578.3 \\
\hline & $\begin{array}{c}\text { Integrated } \\
\text { protection system }\end{array}$ & 90.9 & 111.4 \\
\hline
\end{tabular}

It should be noted that in the study area on maize crops no significant pest damage was observed. In variants without insecticide, especially from the edges of the field was observed hairy corn aphids. The use of Belt insecticide allowed to reduce the population of aphids by 3.5 times, while its number in the colony was much smaller.

In 2019-2020, the most common and harmful diseases on corn cobs were fusarium wilt, gray rot and helminthosporiosis. On variants not treated with fungicides, the development of fusarium wilt ranged from 7.9 to $10.1 \%$, gray rot $-5.8-7.2 \%$ and helminthosporiosis $-13.8-15.2 \%$, depending on the tillage.

When spraying crops with the fungicide Retengo disease development was at the level of 1.0-3.3\%

According to studies, the technical efficiency of the fungicide Retengo on the 14th day after spraying against fusarium wilt was at the level of $87.1-90.0 \%$, gray rot $-78.3-80.1 \%$ and helminthosporiosis 79.4$81.4 \%$, depending on tillage (Table 2). 
ISSN 0130-8521. Передгірне та гірське землеробство і тваринництво. 2021. Вип. 70 (2)

2. The effectiveness of fungicides in maize crops (IAWP NAAS, 20192020)

\begin{tabular}{|c|c|c|c|c|}
\hline \multicolumn{2}{|c|}{ Variant } & \multicolumn{3}{c|}{ Technical efficiency, \% } \\
\cline { 3 - 5 } & fusariosis & gray rot & $\begin{array}{c}\text { helminto- } \\
\text { sporiosis }\end{array}$ \\
\hline \multirow{2}{*}{$\begin{array}{c}\text { Shelf by 20-22 } \\
\mathrm{cm}\end{array}$} & $\begin{array}{c}\text { Without pesticides } \\
\text { (control) }\end{array}$ & 0 & 0 & 0 \\
\cline { 2 - 5 } & $\begin{array}{c}\text { Integrated } \\
\text { protection system }\end{array}$ & 87,3 & 82,7 & 79,7 \\
\hline \multirow{2}{*}{$\begin{array}{c}\text { Shallow by 10- } \\
12 \mathrm{~cm}\end{array}$} & $\begin{array}{c}\text { Without pesticides } \\
\text { (control) }\end{array}$ & 0 & 0 & 0 \\
\hline protection system & 87,1 & 83,8 & 78,3 \\
\hline \multirow{2}{*}{$\begin{array}{c}\text { Surfacial by 6- } \\
8 \mathrm{~cm}\end{array}$} & $\begin{array}{c}\text { Without pesticides } \\
\text { (control) }\end{array}$ & 0 & 0 & 0 \\
\cline { 2 - 5 } & $\begin{array}{c}\text { Integrated } \\
\text { protection system }\end{array}$ & 90,0 & 84,7 & 80,1 \\
\hline
\end{tabular}

On average over the years, research has shown that spraying corn crops with herbicides and fungicides promoted plant development and significantly affected grain yield and quality. Thus, in the variants without herbicides, the height of the plants was 1.7-2.1 m, while by the use of herbicides it was 0.8-0.9 m higher, the length of the cob 3.8-4.1 cm larger $(17.7-19.8 \mathrm{~cm})$. The highest weight of 1000 grains was observed by shelf tillage both on the variant without pesticides $(262.25 \mathrm{~g})$ and by intensive protection $(364.77 \mathrm{~g})$ in comparison with shallow (340.56 g) and surface $(321.63 \mathrm{~g})$ treatments.

The highest yield (11.83 t/ha) was observed by shelf tillage and intensive protection system (Table 3 ). The lack of a protection system reduced this figure by $38.0-41.7 \%$. 
ISSN 0130-8521. Передгірне та гірське землеробство і тваринництво. 2021. Вип. 70 (2)

3. Yield of maize depending on tillage and plant protection (IAWP NAAS, 2019-2020)

\begin{tabular}{|c|c|c|c|c|c|c|c|}
\hline \multirow{2}{*}{\multicolumn{2}{|c|}{ Variant }} & \multicolumn{3}{|c|}{ Repetition } & \multirow{2}{*}{ Mean } & \multicolumn{2}{|c|}{ \pm to control } \\
\hline & & I & II & III & & \multicolumn{2}{|c|}{ Factor AFactor B } \\
\hline \multirow{2}{*}{$\begin{array}{c}\text { Shelf by } 20- \\
22 \mathrm{~cm}\end{array}$} & $\begin{array}{l}\text { Without } \\
\text { pesticides } \\
\text { (control) }\end{array}$ & 6,87 & 6,95 & 6,88 & 6,90 & - & - \\
\hline & \begin{tabular}{|c|} 
Integrated \\
protection system
\end{tabular} & 12,13 & 11,74 & 11,62 & 11,83 & - & $+4,93$ \\
\hline \multirow{2}{*}{$\begin{array}{l}\text { Shallow by } \\
10-12 \mathrm{~cm}\end{array}$} & \begin{tabular}{|c|} 
Without \\
pesticides \\
(control)
\end{tabular} & 6,43 & 6,11 & 6,30 & 6,28 & $-0,62$ & - \\
\hline & \begin{tabular}{|c|} 
Integrated \\
protection system
\end{tabular} & 10,52 & 10,63 & 10,74 & 10,63 & $-1,20$ & $+4,35$ \\
\hline \multirow{2}{*}{$\begin{array}{c}\text { Surfacial by } \\
6-8 \mathrm{~cm}\end{array}$} & \begin{tabular}{|c|} 
Without \\
pesticides \\
(control)
\end{tabular} & 5,40 & 5,36 & 5,31 & 5,36 & $-1,54$ & - \\
\hline & \begin{tabular}{|c|} 
Integrated \\
protection system
\end{tabular} & 8,77 & 8,52 & 8,56 & 8,62 & $-3,21$ & $+3,26$ \\
\hline \multicolumn{2}{|c|}{$\begin{array}{l}\mathrm{LSD}_{05} \text { treatments factor } \mathrm{A} \\
\mathrm{LSD}_{05} \text { protection system factor B } \\
\mathrm{LSD}_{05} \text { interaction }\end{array}$} & & & $\begin{array}{l}0,28 \\
0,22 \\
0,39\end{array}$ & & & \\
\hline
\end{tabular}

Conclusions. Studies have shown that non-shelf tillage shows an increase in weed infestation due to the accumulation of the bulk of weed seeds in the topsoil. Thus, during surface tillage the number of weeds was $545.6 \mathrm{pcs} / \mathrm{m}^{2}$, which is 2 times higher than on the shelf $\left(277.1 \mathrm{pcs} / \mathrm{m}^{2}\right)$. During shelf tillage and herbicide spraying, the number of weeds was 96.8\% lower compared to the control. Somewhat less difference in the impact of tillage was observed on the development and spread of diseases and pests. Against them, the main deterrent is still chemical protection. Tillage allowed to obtain a yield increase of $0.62-1.54 \mathrm{t} / \mathrm{ha}$. The combination of tillage with an intensive protection system led to an increase in yields in the range of 3.26-4.93 t/ha in accordance with the control (5.36$6.90 \mathrm{t} / \mathrm{ha})$

\section{Список використаної літератури}

1. Богданович Р. П. Баланс гумусу в чорноземі типовому легкосуглинковому Правобережного

\section{References}

1. Bohdanovych R. P. Balance of humus in typical loamy chernozem of Right bank Forest-Steppe, taking into account the 
Лісостепу 3 урахуванням нетоварної частини врожаю сільськогосподарських культур. Наукові доповіді Національного університету біоресурсів $\quad$ б природокористування Украӥни. 2014. № 7. URL:

http://nbuv.gov.ua/UJRN/Nd_2014_7_15 (дата звернення: 29.04.2021).

2. Бомба М. Я., Бомба М. І. Бур'яни в агрофітоценозах та екологізація заходів щодо контролювання їх чисельності. Вісник Уманського національного університету садівниитвв. 2019. № 1. С. 15-20. DOI: 10.31395/2310-0478-2019-1$15-20$.

3. Бублик Л. І., Васечко Г. І., Васильєва В. П. Довідник із захисту рослин / за ред. М. П. Лісового. Київ : Урожай, 1999. 744 с.

4. Василенко Р. М., Заєць С. О. Продуктивність кукурудзи залежно від строків сівби та захисту від хвороб та шкідників. Зромуване землеробство. 2017. Вип. 67. С. 69-72.

5. Вох М. В., Антоненко О. Ф., Галиш Ф. С. Поширення i розвиток гельмінтоспоріозу в зонах вирощування кукурудзи. Науковий вісник Начіонального університету біоресурсів $i$ природокористування Украӥни. Сер.: Агрономія. 2012. Вип. 176. С. 296-300.

6. Доспехов Б. А. Методика полевого опыта (с основами статистической обработки результатов исследований). Изд. 5-е, доп. и перераб. Москва, 1985. 351 с.

7. Забур'яненість та врожайність кукурудзи на зерно за системами No-till / В. П. Борона та ін. Вісник аграрної науки. 2013. № 3. С. 24-27.

8. Засміченість посівів зернових культур в короткоротаційних сівозмінах / А. М. Мітрошин та ін. Зб. наук. праць ЛНАУ. 2006. № 58, вип. 81. С. 81-84.

9. Зимароєва А. А. Просторовочасові закономірності варіювання урожайності кукурудзи в Україні. Наукові горизонти. 2019. № 2 (92). С. 58-66. DOI: 10.33249/2663-2144-2019- non commodity part of the crop yield. Naukovi dopovidi Natsionalnoho universytetu bioresursiv $i$ pryrodokorystuvannia Ukrainy. 2014. No. 7. URL:

http://nbuv.gov.ua/UJRN/Nd_2014_7_15

(last accessed: 29.04.2021).

2. Bomba M. Ya., Bomba M. I. Weeds in agrophytocenoses and greening measures to control their numbers. Visnyk Umanskoho natsionalnoho universytetu sadivnytstva. 2019. No. 1. P. 15-20. DOI: 10.31395/2310-0478-2019-1-15-20.

3. Bublyk L. I., Vasechko H. I., Vasylieva V. P. Handbook of plant protection / ed. M. P. Lisovoho. Kyiv : Urozhai, 1999. 744 p.

4. Vasylenko R. M., Zaiets S. O. Maize productivity depending on sowing dates and protection against diseases and pests. Zroshuvane zemlerobstvo. 2017. Issue 67. P. 69-72.

5. Vokh M. V., Antonenko O. F., Halysh F. S. Distribution and development of helminthosporiosis in areas of maize cultivation. Naukovyi visnyk Natsionalnoho universytetu bioresursiv $i$ pryrodokorystuvannia Ukrainy. Ser.: Ahronomiia. 2012. Issue 176. P. 296-300.

6. Dospekhov B. A. Methods of field experience (with the basics of statistical processing of research results). $5^{\text {th }}$ ed. Moscow : Agropromizdat, 1985. $351 \mathrm{p}$.

7. Weediness and yield of corn for grain by systems No-till / V. P. Borona et al. Visnyk ahrarnoi nauky. 2013. No. 3. P. 24-27.

8. Contamination of cereal crops in short-rotation crop rotations / Mitroshyn A. M. et al. Zb. nauk. prats LNAU. 2006. No. 58, Issue 81. P. 81-84.

9. Zymaroieva A. A. Spatio-temporal patterns of variation of corn yield in Ukraine. Naukovi horyzonty. 2019. No. 2 (92). P. 58-66. DOI: 10.33249/2663-21442019-75-2-58-66.

10. Ivashchenko O. O. Ecological control of weeds in wide-row crops. Karantyn i zakhyst roslyn. 2014. No. 3. P. 
ISSN 0130-8521. Передгірне та гірське землеробство і тваринництво. 2021. Вип. 70 (2)

75-2-58-66.

10. Іващенко О. О. Екологічне контролювання бур'янів $\quad \mathrm{y}$ широкорядних посівах. Карантин $i$ захист рослин. 2014. № 3. С. 6-9.

11. Коломієць М. В. Вплив систем обробітку на продуктивність культур і родючість грунту сівозміни. Землеробство. 2000. Вип. 74. С. 23-30.

12. Контролювання бур'янового компоненту у посівах кукурудзи за використання страхових гербіцидів / О. В. Гурманчук та ін. Наукові горизонти. 2020. № 7, вип. 92. С. 53-58. DOI: 10.33249/2663-2144-2020-92-7-53-58

13. Мазур Г. А. Відтворення i регулювання родючості легких грунтів. Київ : Аграрна наука, 2008. 308 с.

14. Манько Ю. П., Кобзиста Л. П. Ефективність контролю забур'яненості. Карантин $і$ захист рослин. 2009. № 2. C. 21-23.

15. Методика випробування i застосування пестицидів / С. О. Трибель та ін. Київ : Світ, 2001. 448 с.

16. Обліки шкідників i хвороб сільськогосподарських культур / за ред. Омелюти В. П. Київ : Урожай, 1986. 202 c.

17. Окрушко С. Є. Контроль чисельності бур'янів у посівах кукурудзи. Захист рослин. 2019. № 14. С. 163-171.

18. Окрушко С. Є. Регулювання чисельності бур'янів у посівах кукурудзи. Молодий вчений. 2019. № 2, вип. 66. C. 319-322. DOI: 10.32839/23045809/2019-2-66-69.

19. Півторайко В. В. Сучасні заходи захисту кукурудзи від шкідників. Матеріали науково-практичної конференції викладачів, аспірантів та студентів Сумського НАУ (м. Суми, 20-21 квіт. 2016 р.). Суми : СНАУ, 2016. C. 271.

20. Продуктивність сортів і гібридів кукурудзи за різних систем удобрення та беззмінного їх вирощування / А. В. Кохан та ін. Вісник аграрної науки. 2019.
6-9.

11. Kolomiiets M. V. Influence of tillage systems on crop productivity and soil fertility of crop rotation. Zemlerobstvo. 2000. Issue 74. P. 23-30.

12. Control of the weed component in maize crops using insurance herbicides / Hurmanchuk O. V. et al. Naukovi horyzonty. 2020. No. 7, Issue 92. P. 53-58. DOI: $\quad 10.33249 / 2663-2144-2020-92-7-53$ 58.

13. Mazur H. A. Reproduction and regulation of light soil fertility. Kyiv : Ahrarna nauka, 2008. 308 p.

14. Manko Yu. P., Kobzysta L. P. Efficacy of weed control. Karantyn $i$ zakhyst roslyn. 2009. No. 2. P. 21-23.

15. Methods of testing and application of pesticides / S. O. Trybel et al. Kyiv : Svit, 2001. 448 p.

16. Accounting for pests and diseases of crops / za redaktsiieiu Omeliuty V. P. Kyiv : Urozhai, 1986. 202 p.

17. Okrushko S. Ye. Weed control in maize crops. Zakhyst roslyn. 2019. No. 14. P. 163-171.

18. Okrushko S. Ye. Weed control in maize crops. Molodyi vchenyi. 2019. No. 2, Issue 66. P. 319-322. DOI: 10.32839/23045809/2019-2-66-69.

19. Pivtoraiko V. V. Modern measures to protect corn from pests. Materialy naukovo-praktychnoi konferentsii vykladachiv, aspirantiv ta studentiv Sumskoho NAU (m. Sumy, 20-21 kvit. 2016 r.). Sumy : SNAU, 2016. P. 271.

20. Productivity of corn varieties and hybrids under different fertilizer systems and their constant cultivation / A. V. Kokhan et al. Visnyk ahrarnoi nauky. 2019. No. 10. P. 18-23. DOI: 10.31073/agrovisnyk201910-03.

21. Soil fertility and yield of field crops under different systems of cultivation and fertilization in crop rotation / E. M. Lebid et al. Visnyk DDAU. 2013. No. 2, Issue 32. P. 26-31.

22. Serhiienko V., Horbach T. Herbicide control on corn. Ahrobiznes 
ISSN 0130-8521. Передгірне та гірське землеробство і тваринництво. 2021. Вип. 70 (2)

№ $10 . \quad$ C. $18-23 . \quad$ DOI: sohodni. 2012. No. 4. P. 20-24.

10.31073/agrovisnyk201910-03.

23. Snizhok O. V. Control of weeds

21. Родючість грунту та врожайність польових культур за різних систем обробітку та удобрення в сівозміні / Е. М. Лебідь та ін. Вісник ДДАУ. 2013. № 2, вип. 32. С. 26-31.

22. Сергієнко В., Горбач T. Гербіцидний контроль на кукурудзі Агробізнес сьогодні. 2012. № 4. С. $20-24$.

23. Сніжок О. В. Контроль бур'янів та хвороб на кукурудзі баковими сумішами. Пропозииія. 2017. № 6. С. 102-103.

24. Стабільність та пластичність гібридів кукурудзи залежно від системи удобрення та густоти стояння рослин в Правобережному Лісостепу України / В.

Г. Таран та ін. Біоресурси $i$ природокористування. 2018. № 3/4, т. 10. C. 147-156. DOI: 10.31548/bio2018.03.019.

25. Трибель С. О., Стригун О. О., Ретьман С. В. Концепція удосконалення системи захисту посівів кукурудзи. Захист і карантин рослин. 2010. № 56. C. 159-181.

26. Федоренко В. П., Пащенко Ю. М., Дудка Е. Л. Защита кукурузы при интенсивной технологии ее возделывания. Защита и карантин растений. 2011. № 5. С. 17-24.

27. Швартау В. В., Мордерер Є. Ю. Розробка та впровадження екологічно безпечних технологій боротьби 3 бур'янами. Карантин $i$ захист рослин. 2010. № 9. C. 10-22.

28. Яровенко В. В., Зінченко В. І., Женченко К. Г. Способи обробітку грунту і розміщення насіння бур'янів по шарах грунту. Вісник аграрної науки. 1997. № 8. C. 5-7.

29. Geis P. Application and timing effects of QOI and DMI fungicides and a foliar fertilizer on overall plant health and grain yield in corn: diss. of master degree. Purdue University e-Pubs. Open Access Theses. West Lafayette, 2014. P. 152. URL: and diseases on corn by lateral mixes. Propozytsiia. 2017. No. 6. P. 102-103.

24. Stability and plasticity of maize hybrids depending on fertilizer system and plant density in the Right bank Forest-Steppe of Ukraine / V. H. Taran et al. Bioresursy $i$ pryrodokorystuvannia. 2018. No. 3/4, Vol. 10. P. 147-156. DOI: 10.31548/bio2018.03.019.

25. Trybel S. O., Stryhun O. O., Retman S. V. The concept of improving the system of protection of corn crops. Zakhyst $i$ karantyn roslyn. 2010. No. 56. P. 159-181.

26. Fedorenko V. P., Pashchenko Yu. M., Dudka E. L. Protection of corn at intensive technology of its cultivation. Zashhita i karantin rastenij. 2011. No. 5. P. 17-24.

27. Shvartau V. V., Morderer Ye. Yu. Development and implementation of environmentally friendly weed control technologies. Karantyn $i$ zakhyst roslyn. 2010. No. 9. P. 10-22.

28. Yarovenko V. V., Zinchenko V. I., Zhenchenko K. H. Methods of tillage and placement of weed seeds on the soil layers. Visnyk ahrarnoi nauky. 1997. No. 8. P. 5-7.

29. Geis P. Application and timing effects of QOI and DMI fungicides and a foliar fertilizer on overall plant health and grain yield in corn : diss. of master degree. Purdue University e-Pubs. Open Access Theses. West Lafayette, 2014. P. 152. URL: https://docs.lib.purdue.edu/open access the

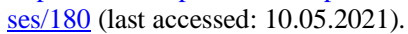

30. Grain: World Markets and Trade. United States Department of Agriculture Foreign Agricultural Service. 2020. P. 12-44.

URL:

https://apps.fas.usda.gov/psdonline/circulars /grain-corn-coarsegrains.pdf (last accessed: 10.05.2021).

31. Schleicher C., Jackson-Ziems T. Evaluation of Application Timing of Foliar Fungicides on Efficacy of Field Corn in 
ISSN 0130-8521. Передгірне та гірське землеробство і тваринництво. 2021. Вип. 70 (2)

https://docs.lib.purdue.edu/open access the ses/180 (last accessed: 10.05.2021).

30. Grain: World Markets and Trade. United States Department of Agriculture Foreign Agricultural Service. $2020 . \quad$ P. 12-44. https://apps.fas.usda.gov/psdonline/circulars /grain-corn-coarsegrains.pdf (last accessed: 10.05.2021).

31. Schleicher C., Jackson-Ziems T. Evaluation of Application Timing of Foliar Fungicides on Efficacy of Field Corn in Central Nebraska, 2011. Papers in Plant Pathology. 2012. URL: http://digitalcommons.unl.edu/plantpathpap ers/516 (last accessed: 14.05.2021).
Central Nebraska, 2011. Papers in Plant Pathology. 2012. URL: http://digitalcommons.unl.edu/plantpathpap ers/516 (last accessed: 14.05.2021). 